\title{
Marcin Gębarowski
}

Uniwersytet Ekonomiczny w Krakowie

e-mail: marcin.gebarowski@uek.krakow.pl

\section{KONCEPCJA BADANIA STOISK TARGOWYCH Z WYKORZYSTANIEM METODY EYE TRACKING*}

\section{CONCEPTUALISATION OF EYE-TRACKING RESEARCH OF TRADE FAIR BOOTHS}

DOI: $10.15611 /$ pn.2018.525.19

JEL Classification: D91, M31

Streszczenie: Celem artykułu jest przedstawienie koncepcji badań aktywności marketingowej wystawców z wykorzystaniem mobilnego eye trackera. Skoncentrowano się na ogólnym wyglądzie stoisk oraz na ich części ekspozycyjnej, czyli strefie, w której - za pomocą produktów lub innych eksponatów (np. modeli, filmów, plansz) - wizualnie prezentuje się ofertę targową. Opracowanie wypełnia lukę w literaturze, gdyż w Polsce nie wykorzystano jeszcze eye trackingu podczas wydarzeń wystawienniczych, a w zagranicznym piśmiennictwie naukowym znajdują się tylko lapidarne wzmianki o zastosowaniu tej metody w przestrzeni targowej. W sensie ogólnym przedstawiono genezę oraz przebieg badań okulograficznych. W odniesieniu do targów natomiast zaproponowano możliwe obszary wykorzystania mobilnego eye trackera oraz zidentyfikowano ograniczenia wiążące się z zastosowaniem tego urządzenia.

Slowa kluczowe: targi, stoiska targowe, badania marketingowe, eye tracking.

Summary: This paper presents a concept of research into the exhibitors' marketing activity using a mobile eye tracker. Attention focuses on the general design of booths and their demonstration area, that is to say, a zone where - by means of products or other showpieces (e.g. using models, films, display boards) - a trade fair offer is presented visually. This work fills a gap in the literature, since eye tracking has never been used at any Polish exhibition event thus far, and as regards international scientific publications, only some of them contain succinct references to the adoption of the method in question in the trade fair environment. In a general sense, the paper shows the origin and conduct of eye tracking. As far as trade fair is concerned, the possible areas for the use of the mobile eye tracker were proposed, as well as the limitations relating to the use of such a device were identified.

Keywords: trade fair, booths, marketing research, eye tracking.

* Publikacja sfinansowana ze środków przyznanych Wydziałowi Towaroznawstwa i Zarządzania Produktem Uniwersytetu Ekonomicznego w Krakowie w ramach dotacji na utrzymanie potencjału badawczego. 


\section{Wstęp}

Zabieganie o uwagę uczestników targów odbywa się w dużej mierze w wymiarze wizualnym. Skuteczne pozyskiwanie zainteresowania zwiedzających jest szczególnie istotne w fazie wyboru ekspozycji, gdyż podczas dużych targów specjalistycznych, wiodących w swoich branżach, w których uczestniczy kilka tysięcy wystawców, zwiedzający nie jest w stanie odwiedzić wszystkich stanowisk. Zatrzyma się on prawdopodobnie przy tych, które sam wybierze ze spisu wystawców (ze względu na konieczność spotkania się z dotychczasowymi lub przyszłymi partnerami biznesowymi, jak również zobaczenia ekspozycji konkurentów rynkowych), lub tych, które silnie przyciągną jego uwagę (kolorystką, nietypową formą, spektakularnym programem wystąpienia targowego). Zakłada się, że goście targowi poświęcają mniej niż $5 \mathrm{~s}$ na to, aby szybko przyjrzeć się prezentacjom, w pobliżu których przechodzą, i zdecydować, czy zatrzymać się przy konkretnym stoisku [Smith 1993, s. 308]. Po wyborze prezentacji ważne jest także to, jakie wrażenie zrobi na uczestnikach targów wnętrze stoiska, w tym przede wszystkim jego strefa ekspozycyjna.

Metodą, której zastosowanie pozwoliłoby uzyskać wyniki umożliwiające optymalizację wyglądu stoisk, jest eye tracking. Badaniom okulograficznym poświęcono jednak niewiele uwagi w publikacjach naukowych z zakresu marketingu targowego. $\mathrm{W}$ związku z tym celem niniejszego opracowania jest zaproponowanie koncepcji badania wizualnych wymiarów prezentacji targowych z wykorzystaniem mobilnego eye trackera.

\section{Geneza badań okulograficznych oraz obszary ich zastosowań}

Geneza badań ruchu gałek ocznych sięga 1879 r., gdy to francuski uczony L.É. Javal zbudował urządzenie do pomiaru przemieszczania się wzroku. Opracowane rozwiązanie było inwazyjne, a uciążliwość metody polegała na fizycznym nałożeniu znacznika urządzenia bezpośrednio na gałkę oczną badanej osoby. W $1901 \mathrm{r}$. R. Dodge i T.S. Cline skonstruowali pierwszy okulograf nieinwazyjny, który wysyłał wiązkę światła odbijającą się od oka i padającą przez odpowiedni układ optyczny na światłoczułą płytkę fotograficzną. W ten sposób powstawał zapis umożliwiający przeanalizowanie ruchu oka. To urządzenie miało znaczący mankament, gdyż pozwalało tylko na zapis ruchu poziomego oka. W 1905 r. C.H. Judd, C.N. McAlister oraz W.M. Steel opracowali rozwiązanie składające się z przyczepianego do oka mechanicznego znacznika oraz odbiornika zapisującego odbitą plamkę światła na taśmie światłoczułej. Badanie to umożliwiało już zapis dwuwymiarowy, co dawało możliwość zwiększenia zakresu badań. Mimo dalszego rozwoju technologii eyetrackingowej, urządzenia nie były wygodne w użyciu, wymagały bowiem unieruchomienia głowy przez badaną osobę. Zmieniło się to w 1948 r., gdy H. Hertridge i L.C. Thompson opracowali okulograf nakładany na głowę i spełniający wszystkie funkcje przyrządu stacjonarnego. Urządzenie, oprócz zalety w postaci mobilności, 
miało istotną wadę - było niewygodne. Każdy ruch badanej osoby zaburzał wyniki pomiarów. W późniejszych latach wielokrotnie udoskonalano urządzenia eyetrackingowe, wykorzystując osiągnięcia elektroniki oraz technologii informatycznych. Ewoluowały również rodzaje badań oraz metody prezentowania wyników do stanu, jaki występuje obecnie [Czerski, Wawer 2009, s. 129-130]. Eye tracking rozwija się zatem przez ponad sto lat, a uzyskiwane za pomocą tej metody rezultaty opisywane są w literaturze naukowej od kilku dekad.

Zwiększone zainteresowanie badaniami okulograficznymi w piśmiennictwie naukowym obserwowane jest w ciągu ostatnich lat. Możliwości zastosowania metody eye tracking prezentowano przede wszystkim $\mathrm{w}$ odniesieniu do: pedagogiki [Liu 2014; Andrzejewska i in. 2016; Was, Sansosti, Morris 2017], psychologii [Palanica, Itier 2011; Elsner i in. 2013; Traczyk, Kus, Sobkow 2017], medycyny [Chetwood i in. 2012; Falck-Ytter, Bölte, Gredebäck 2013; Lanzer i in. 2017], ergonomii [Hasse, Bruder 2015; Michalski 2017; Kim, Zhao, Du 2018] oraz muzealnictwa [Wawer, Pakuła 2012; Eghbal-Azar, Widlok 2013; Mokatren, Kuflik, Shimshoni 2017]. Eye tracking znalazł także swoje miejsce w publikacjach z zakresu marketingu, które poświęcono głównie: reklamie tradycyjnej [Champlin i in. 2014; Boerman, Reijmersdal, Neijens 2015; Puškarević i in. 2016], reklamie internetowej [Hervet i in. 2011; Lee, Ahn 2012; Barreto 2013], stronom WWW [Zambarbieri, Carniglia, Robino 2008; Çınar 2009; Bergstrom, Olmsted-Hawala, Jans 2013], merchandisingowi [Behe i in. 2013; Huddleston i in. 2015; Wästlund, Shams, Otterbring 2018] oraz opakowaniom [Turner i in. 2014; Cholewa-Wójcik, Świda 2015; Husić-Mehmedović i in. 2017]. Nadal jednak istnieją obszary marketingu, w których kontekście nie opisano lub opisano w niewielkim stopniu możliwości wykorzystania badań okulograficznych. Jednym z takich obszarów jest marketing targowy.

\section{Realizacja badania metodą eye tracking}

W ogólnym ujęciu można przyjąć, że metoda eye tracking sprowadza się do śledzenia ruchu gałek ocznych uczestników badania patrzących na określony obiekt i jednoczesnego zapisywania sakad oraz fiksacji. Sakady to intensywne ruchy gałki ocznej, polegające na bardzo szybkim przemieszczaniu punktu koncentracji wzro$\mathrm{ku} \mathrm{z}$ jednego miejsca na inne (sakady trwają od 20 do $40 \mathrm{~ms}$ ). Z kolei fiksacja to relatywnie stała pozycja gałki ludzkiego oka, w trakcie której następują niewielkie drgania. Fiksacje stabilizują siatkówkę nad nieruchomym obiektem (są one niezwykle krótkie i trwają od 100 do 600 ms). Przyjmuje się, że podczas fiksacji ma miejsce proces poznawczy - tzn. informacje wzrokowe docierają do mózgu i są tam świadomie przetwarzane. Oprócz określania sakad i fiksacji typowy pomiar eyetrackingowy opiera się na analizie całkowitego oraz średniego czasu poświęconego na oglądanie obiektu, jak również wskazaniu rewizyt - ponownego oglądania danych elementów [Cholewa-Wójcik, Kawecka 2015, s. 53; Garczarek-Bąk 2016, s. 58]. 
W wymiarze technicznym funkcjonowanie większości nowoczesnych modeli eye trackerów opiera się na metodzie nazywanej odbiciem rogówki, polegającej na wykryciu i śledzeniu położenia oraz ruchów gałek ocznych. Kamera o dużej rozdzielczości wykrywa położenie źrenic, które oświetlane są niewidzialnym dla człowieka światłem podczerwonym. Podczerwień odbija się od oczu, tworząc odbicia stanowiących dobrze widoczne w źrenicach refleksy. Za ich pomocą można zidentyfikować miejsce, na które $\mathrm{w}$ danym momencie patrzy badana osoba. Eye tracking umożliwia zatem bardzo precyzyjne pomiary zachowań gałek ocznych. W literaturze przedmiotu wyróżnia się trzy podstawowe atrybuty badań okulograficznych, takie jak: lokalizacja, czas trwania i ruch [Garczarek-Bąk 2016, s. 58].

Dokonując pewnej symplifikacji, można przyjąć, że dostępne na rynku eye trackery to rozwiązania stacjonarne oraz urządzenia mobilne. Eye trackery stacjonarne często nie różnią się wyglądem od monitora komputera, natomiast okulografy mobilne najczęściej zakłada się na głowę badanych osób. W obu przypadkach proces pomiaru ruchu źrenic dokonuje się „w tle” i nie ogranicza swobodnego sposobu zachowania respondenta podczas jego patrzenia na konkretny obiekt. Urządzenia $\mathrm{w}$ wersji mobilnej pozwalają na zgromadzenie danych $\mathrm{w}$ naturalnym środowisku dla osoby badanej (np. w sklepie, podczas jazdy samochodem). Ruchy źrenic rejestrowane są przez eye tracker, a następnie, dzięki zastosowaniu radiowej komunikacji urządzenia ze stacją roboczą, przesyłane do tej ostatniej, gdzie poddawane są obróbce cyfrowej, po której następuje analiza i interpretacja zebranego materiału [Wąsikowska 2015, s. 150-151].

Badania eyetrackingowe zaliczane są do metod jakościowych. Mają one jednak zastosowanie także w badaniach ilościowych - w sytuacjach gdy badania prowadzone są na dużych próbach respondentów (powyżej 30 osób). Zakłada się, że minimalna wielkość próby w badaniach okulograficznych wynosi od 8 do 10 respondentów (przy założeniu powtarzalności pomiaru) [Stolecka-Makowska, Wolny 2014, s. 202]. Wstępne wyniki pomiaru dokonanego metodą eye tracking można obejrzeć już po zakończeniu badania. Uzyskane rezultaty przedstawia się najczęściej w formie map cieplnych, które są rozkładem uwagi kierowanej na dany obszar, z możliwością wyodrębnienia elementów zauważonych i pominiętych podczas skanowania wzroku. Mapy cieplne przy pomocy barw pokazują uśredniony obraz obszarów widzianego obiektu, na których badani skupiali swój wzrok. Miejsca, na których wzrok skupiał się najczęściej, oznaczone zostają barwą czerwoną. Obszary, w których dochodziło do mniejszej liczby spojrzeń, wskazane zostają na żółto, natomiast miejsca, gdzie było ich najmniej - na zielono. Barwy mapy prezentują łączną liczbę i czas fiksacji, czyli punktów, w których wzrok badanych osób zatrzymał się w danym obszarze. Oprócz map cieplnych podczas analizowania uzyskanych wyników często stosuje się ścieżkę skanowania wzroku, pokazującą kolejność aktywności wzrokowej badanych osób w ramach wytyczonych przez badacza tzw. obszarów zainteresowania (AOI - area of interest) [Cholewa-Wójcik 2016, s. 13]. 
Za sprawą wprowadzania nowych rozwiązań - zarówno w samych urządzeniach, jak i oprogramowaniu - eye trackery znajdują coraz szersze zastosowanie. Wykorzystując okulografię, można bowiem dokonać diagnozy zoptymalizowania każdego komunikatu opierającego się na percepcji wzrokowej człowieka. Od momentu powstania eye trackingu wiązało się nim hasło: „wiesz, co widzi twój klient” [por. Rzemieniak 2012, s. 90]. Dzięki ciągłemu rozwojowi rozpatrywanej metody hasło to staje się realne jak nigdy wcześniej.

\section{Propozycja wykorzystania metody eye tracking do badania wizualnych aspektów prezentacji targowych}

Jak już zauważono, w literaturze istnieje niedobór prac naukowych, które opisywałyby zastosowanie metody eye tracking podczas wydarzeń wystawienniczych. Jedyną publikacją, która odnosi się wprost do tego zagadnienia, jest opracowanie M. Kirchgeorga oraz B. Ermer [2012]. Autorzy zaprezentowali wyniki badań okulograficznych przeprowadzonych w odniesieniu do stoiska wybranego podmiotu z branży energetycznej, wykorzystanego podczas jednej z edycji targów E-world energy \& water, które odbywają się w Essen. Autorzy w swojej publikacji zastosowali mobilny eye tracker w dwóch wariantach: (1) w środowisku laboratoryjnym, gdy uczestnicy badania patrzyli na dwuwymiarowe, renderowane, przedstawione w różnych rzutach zdjęcia projektów stoiska (próba badawcza liczyła 56 osób); (2) w rzeczywistych warunkach targowych, gdy prawdziwi zwiedzający zostali zrekrutowani do badania (34 osoby). W drugim wariancie dodatkowo wykreowano dwie sytuacje badawcze - w pierwszej z nich osoby obserwujące nie były świadome, że stoisko jest głównym obiektem badania, w drugiej zaś - uczestnicy badania zostali jednoznacznie poproszeni o przyjrzenie się stoisku. O ile wyniki badań laboratoryjnych oraz tych zrealizowanych podczas targów okazały się niemal identyczne, o tyle ukierunkowanie świadomości badanych na obserwację stoiska znacznie wpłynęło na otrzymane wyniki. Z badania przeprowadzonego przez niemieckich naukowców wyłaniają się ogólne konkluzje wskazujące na to, że za sprawą analizy danych pozyskanych przy pomocy eye trackera można uzyskać istotne dla wystawców informacje dotyczące tego, na które elementy stanowiska ekspozycyjnego wzrok zwiedzających wędruje najczęściej i jaki jest czas fiksacji. Ponadto można określić, które elementy stoiska wspierają przesłanie wystawcy oraz czy są spójne z tożsamością jego marki. Badanie przeprowadzone $\mathrm{w}$ realnych warunkach targowych pokazało, że tym, co silnie przyciąga wzrok uczestników targów, są nie tylko wizualne elementy ekspozycji, ale również ludzie przebywający na stoiskach [Kirchgeorg, Ermer 2012, s. 259-265].

Proces realizacja badania metodą eye tracking można ująć w postaci następujących etapów: (1) zdefiniowanie pytań badawczych, określenie obiektu oraz jednostek badania; (2) wybór techniki okulograficznej oraz miejsca prowadzenia badań; (3) rekrutacja uczestników badania; (4) pobieranie i gromadzenie danych; (5) analiza danych oraz ich interpretacja; (6) przygotowanie oraz prezentacja wyników badania 
[por. Stolecka-Makowska, Wolny 2014, s. 198]. W odniesieniu do targów specyfika tego procesu zarysowuje się przede wszystkim na drugim etapie, gdyż obiektem badania może być ogólny wygląd stoisk lub ich wybrane elementy (np. strefy ekspozycyjne), jednostkami badawczymi są zaś pojedynczy zwiedzający. Ponadto w szczególny sposób będzie przebiegała rekrutacja uczestników badania, gdyż będą to osoby przybyłe na targi w charakterze zwiedzających. Takim osobom, szczególnie podczas wydarzeń specjalistycznych (organizowanych głównie z myślą o rynkach B2B), towarzyszy pośpiech, a atmosfera targowa charakteryzuje się niemal zawsze sporym zamieszaniem i wiąże się z funkcjonowaniem zwiedzających w thumie. Te niekorzystne zjawiska wywrą wpływ na rekrutację „w terenie”, utrudniając potencjalnym badanym wyjaśnienia założeń badawczych oraz skłonienie ich do założenia mobilnego okulografu (osobę, która przybyła na targi realizować ważne cele biznesowe, trudno będzie nakłonić do noszenia nietypowych okularów, zawierających wbudowaną kamerę).

W kontekście wykorzystania mobilnego eye trackera podczas targów należy wskazać na trzy możliwe obszary badań. Pierwszy z nich to określenie, w jakim stopniu konkretne stoisko skutecznie przyciąga wzrok osób przemieszczających się po hali targowej - sprawdzenie, jak bardzo wyróżnia się ono na tle innych stanowisk. Drugi obszar to określenie, które elementy pojedynczego stoiska zwracają najsilniej uwagę osób stojących przed nim. Trzeci aspekt badawczy to zainteresowanie osób przebywających wewnątrz stoiska - w strefie ekspozycyjnej - elementami wystąpienia targowego, na których szczególnie zależy wystawcy (np. prezentowanymi produktami, modelami, makietami, planszami). Strefa ekspozycyjna ma kluczowe znaczenie dla właściwego pokazania oferty targowej i jest jedną z czterech części składających się na typowe stoiska (oprócz strefy informacyjnej - służącej do nawiązywania pierwszego kontaktu z klientami, strefy recepcyjnej - miejsca do przyjmowania gości i prowadzenia z nimi rozmów, zaplecza technicznego - z kuchnią, szatnią, magazynem itd.). W odniesieniu do drugiego oraz trzeciego obszaru kluczowe będzie wskazanie tzw. obszarów zainteresowań (AOI), czyli elementów obserwowanych stoisk, które są przedmiotem szczególnej uwagi badaczy. Określenie takich elementów umożliwi odseparowanie ze wszystkich spojrzeń tych, które dotyczą tych wyodrębnionych miejsc.

Należy przypuszczać, że badania okulograficzne przyniosą zamierzone efekty w przypadku stoisk autorskich, budowanych według indywidulanych projektów i odznaczających się nietypowym kształtem oraz kolorystyką. Wykorzystanie eye trackera może okazać się nieuzasadnione podczas targów, na których dominuje zabudowa standardowa (oktagonalna), charakteryzująca się niedużymi boksami otoczonymi białymi ściankami, gdy prezentacje większości wystawców są podobne. Ponadto realizowanie badań okulograficznych koncentrujących się na strefie ekspozycyjnej będzie miało sens w odniesieniu do dużych stanowisk, w których strefa ta wyraźnie odróżnia się od pozostałych obszarów stoisk. 
Eye tracking może stanowić, w ramach triangulacji metod badawczych, uzupełnienie innych metod. Kluczową kwestią, którą należy wskazać w tym kontekście, jest obiektywizm tej metody na tle pozostałych stosowanych dotychczas metod badań aktywności marketingowej wystawców. Zarówno ankieta audytoryjna, jak i wywiad bezpośredni opierają się na deklaracjach respondentów reprezentujących wystawiające się podmioty. Z kolei badanie typu „tajemniczy zwiedzający” (mystery visitor) dokonywane jest przez pryzmat subiektywnego spojrzenia obserwatora. W przypadku badań okulograficznych obiektywne dane liczbowe zbiera i przetwarza urządzanie wraz z oprogramowaniem, pozbawione tych mankamentów.

\section{Podsumowanie}

To właśnie zmysł wzroku jest najbardziej angażowany ze wszystkich zmysłów człowieka w procesie postrzegania otaczającego go świata. Przyjmuje się, że ok. 70\% receptorów ciał zmysłowych człowieka znajduje się w jego oczach i mniej więcej jedna czwarta ludzkiego mózgu jest angażowana w proces widzenia [Pradeep 2010, s. 42]. Należy zatem wskazać na potrzebę włączania badań okulograficznych do badania aktywności marketingowej wystawców.

Dominujące znaczenie zmysłu wzroku w procesach percepcyjnych to tylko jedno ze wskazań wykorzystania metody eye tracking podczas wydarzeń wystawienniczych. Inna przesłanka to cechy współczesnych targów, które gromadząc w jednym miejscu oraz czasie licznych przedstawicieli stron podaży i pobytu z danej branży, otwarcie komunikujących się, stanowią dogodną przestrzeń do poszukiwania nowych metod badawczych. W literaturze przedmiotu targi nazwane zostały nawet ,laboratorium badań marketingowych" [Solberg Søilen 2013, s. 1].

Na podstawie wyników badania przeprowadzonego przez M. Kirchgeorga oraz B. Ermer [2012] można przyjąć, że zastosowanie badań okulograficznych już na etapie projektowania ekspozycji pozwala zoptymalizować koncepcję stoiska w kontekście przyjętych celów aktywności targowej, a tym samym przyczynia się do racjonalizacji działań wystawców. Jednak w świetle dokonań niemieckich naukowców należy zwrócić uwagę na to, że ich badanie dotyczyło tylko stoiska jednego wystawcy - służyło ocenie wyboru najlepszego projektu ekspozycji pod kątem jej walorów wizualnych. W tym projekcie badawczym pominięto ocenę rozpatrywanego stoiska na tle stanowisk innych wystawców, jak również nie zbadano jego najważniejszego sektora - części ekspozycyjnej. W odniesieniu do badania zrealizowanego w Niemczech należy także wskazać na konieczność przeprowadzenia pogłębionej eksploracji, pozwalającej precyzyjnie określić, w jakim stopniu wyniki badania projektów stoisk w warunkach laboratoryjnych pokrywają się z postrzeganiem stoisk w rzeczywistych realiach wystawienniczych. W przestrzeni targowej występuje bowiem duże zamieszanie i wynikająca z niego znaczna liczba dystraktorów zakłócających procesy percepcyjne, których nie można odtworzyć w warunkach laboratoryjnych. Ponadto dokładniejszego rozeznania wymaga kwestia fiksacji wzroku nie tylko na 
elementach ekspozycji, ale również na osobach przebywających na stoiskach (na personelu reprezentującym wystawców oraz gościach targowych).

Badania okulograficzne umożliwiają zoptymalizowanie wyglądu pojedynczego stoiska - tak, aby w sferze wizualnej skutecznie spełniało cele aktywności targowej. W przyszłych badaniach warto jednak zastosować mobilną wersją eye trackera w ogólnym kontekście - odnoszącym się do wielu stoisk. Przeprowadzenie takich obserwacji pozwoli na wyciągnięcie wniosków rozszerzających zakres dotychczas znanych i stosowanych reguł marketingu targowego, a tym samym przyczyni się do lepszego wykorzystania potencjału współczesnych wydarzeń wystawienniczych.

Barierą dla wprowadzenia okulografii do praktyki badawczej w halach targowych jest przede wszystkim wysoki koszt zakupu mobilnego eye trackera oraz brak świadomości wśród naukowców co do możliwości wykorzystania tego typu badań w odniesieniu do wystawców. Ten drugi aspekt jest przejawem szerszego zjawiska, jakim jest obserwowane w Polsce niewielkie zainteresowanie badaniami marketingowymi mieszczącymi się w sferze marketingu targowego - na rodzimych uczelniach tylko kilka osób zajmuje się w swojej pracy naukowej wydarzeniami wystawienniczymi, a jedyną organizacją wspierającą takie działania jest Polska Izba Przemysłu Targowego. Należy spodziewać się jednak, że coraz szersze wykorzystywanie badań okulograficznych w różnych obszarach aktywności marketingowej (m.in. handlu detalicznym, internecie, opakowalnictwie), jak również ciągły rozwój urządzeń eyetrackingowych przyczynią się do rozpoczęcia realizowania badań tą metodą wśród uczestników targów.

\section{Literatura}

Andrzejewska M., Stolińska A., Błasiak W., Pęczkowski P., Rosiek R., Rożek B., Sajka M., Wcisło D., 2016, Eye-tracking verification of the strategy used to analyse algorithms expressed in a flowchart and pseudocode, Interactive Learning Environments, vol. 24, iss. 8, s. 1981-1995.

Barreto A.M., 2013, Do users look at banner ads on Facebook?, Journal of Research in Interactive Marketing, vol. 7, iss. 2, s. 119-139.

Behe B.K., Zhao J., Sage L., Huddleston P.T., Minahan S., 2013, Display signs and involvement: the visual path to purchase intention, The International Review of Retail, Distribution and Consumer Research, vol. 23, iss. 5, s. 511-522.

Bergstrom J.C.R., Olmsted-Hawala E.L., Jans M.E., 2013, Age-Related Differences in Eye Tracking and Usability Performance: Website Usability for Older Adults, International Journal of HumanComputer Interaction, vol. 29, iss. 8, s. 541-548.

Boerman S.C., van Reijmersdal E.A., Neijens P.C., 2015, Using Eye Tracking to Understand the Effects of Brand Placement Disclosure Types in Television Programs, Journal of Advertising, vol. 44, iss. 3, s. 196-207.

Champlin S., Lazard A., Mackert M., Pasch K.E., 2014, Perceptions of design quality: An eye tracking study of attention and appeal in health advertisements, Journal of Communication in Healthcaref, vol. 7, iss. 4, s. 285-294.

Chetwood A.S., Kwok K.-W., Sun L.-W., Mylonas G.P., Clark J., Darzi A., Yang G.-Z., 2012, Collaborative eye tracking: a potential training tool in laparoscopic surgery, Surgical Endoscopy, vol. 26, iss. 7, s. 2003-2009. 
Cholewa-Wójcik A., 2016, Weryfikacja możliwości wykorzystania nieparametrycznego testu niezależności do analizy postrzegania wybranych elementów komunikacji wizualnej opakowań, Humanities and Social Sciences, vol. 21 (XXI), no. 23(3), s. 9-22.

Cholewa-Wójcik A., Kawecka A., 2015, The influence of effectiveness of packaging elements on the consumers' preferences with the use of marketing eye-tracking technique, Modern Management Review, vol. 20 (XX), no. 22(1), s. 49-61.

Cholewa-Wójcik A., Świda J., 2015, A study and assessment of selected elements of the visual aspects of collectible chocolate packaging with the use of the eye-tracking method, Indian Journal of Marketing, vol. 45, iss. 7, s. 7-18.

Çınar M.O., 2009, Eye Tracking Method to Compare the Usability of University Web Sites: A Case Study, [w:] Kurosu M. (ed.), Human Centered Design, Lecture Notes in Computer Science, vol. 5619, Springer, Berlin-Heidelberg.

Czerski W., Wawer R., 2009, Badania eyetrackingowe - historia i teraźniejszość, [w:] Jastriebow A. (red.), Informatyka $w$ dobie XXI wieku. Technologie informatyczne w nauce, technice i edukacji, Politechnika Radomska, Radom, s. 129-132.

Eghbal-Azar K., Widlok T., 2013, Potentials and limitations of mobile eye tracking in visitor studies. Evidence from field research at two museum exhibitions in Germany, Social Science Computer Review, vol. 31, iss. 1, s. 103-118.

Elsner C., D'Ausilio A., Gredebäck G., Falck-Ytter T., Fadiga L., 2013, The motor cortex is causally related to predictive eye movements during action observation, Neuropsychologia, vol. 51, iss. 3 , s. $488-492$.

Falck-Ytter T., Bölte S., Gredebäck G., 2013, Eye tracking in early autism research, Journal of Neurodevelopmental Disorders, vol. 5(1), iss. 28, s. 1-13.

Garczarek-Bąk U., 2016, Użyteczność badań eye trackignowych w pomiarze utajonych determinant zachowań zakupowych nabywców, Ekonometria, nr 3(53), s. 54-71.

Hasse C., Bruder C., 2015, Eye-tracking measurements and their link to a normative model of monitoring behavior, Ergonomics, vol. 58, iss. 3, s. 355-367.

Hervet G., Guérard K., Tremblay S., Chtourou M.S., 2011, Is banner blindness genuine? Eye tracking internet text advertising, Applied Cognitive Psychology, vol. 25, iss. 5, s. 708-716.

Huddleston P.T., Behe B.K., Minahan S., Fernandez R.T., 2015, Seeking attention: an eye tracking study of in-store merchandise displays, International Journal of Retail \& Distribution Management, vol. 43, iss. 6, s. 561-574.

Husić-Mehmedović M., Omeragić I., Batagelj Z., Kolar T., 2017, Seeing is not necessarily liking: Advancing research on package design with eye-tracking, Journal of Business Research, vol. 80, s. $145-154$.

Kim J.H., Zhao X., Du W., 2018, Assessing the performance of visual identification tasks using time window-based eye inter-fixation duration, International Journal of Industrial Ergonomics, vol. 64, s. $15-22$.

Kirchgeorg M., Ermer B., 2012, Wahrnehmungswirkung von Messeständen als temporären Markenerlebniswelten, [w:] Bruhn M., Hadwich K. (Hrsg.), C Customer Experience: Forum Dienstleistungsmanagement, Springer Gabler, Wiesbaden, s. 251-271

Lanzer P., Al-Naser M., Bukhari S.S., Dengel A.R., Krupinski E.A., 2017, Eye tracking in catheter-based cardiovascular interventions: Early results, Journal of Medical Imaging, vol. 4, iss. 3.

Lee J.W., Ahn J.-H., 2012, Attention to banner ads and their effectiveness: An eye-tracking approach, International Journal of Electronic Commerce, vol. 17, iss. 1, s. 119-137.

Liu P.-L., 2014, Using eye tracking to understand learners' reading process through the concept-mapping learning strategy, Computers \& Education, vol. 78, s. 237-249.

Michalski R., 2017, Information presentation compatibility in a simple digital control panel design: eye-tracking study, International Journal of Occupational Safety and Ergonomics (w druku). 
Mokatren M., Kuflik T., Shimshoni I., 2017, Exploring the potential of a mobile eye tracker as an intuitive indoor pointing device: A case study in cultural heritage, Future Generation Computer Systems (w druku).

Palanica A., Itier R.J., 2011, Searching for a perceived gaze direction using eye tracking, Journal of Vision, vol. 11, s. 1-13.

Pradeep A.K., 2010, The Buying Brain. Secrets for Selling to the Subconscious Mind, John Wiley \& Sons, Hoboken.

Puškarević I., Nedeljković U., Dimovski V., Možina K., 2016, An eye tracking study of attention to print advertisements: Effects of typeface figuration, Journal of Eye Movement Research, vol. 9, no. 5, s. 1-18.

Rzemieniak M., 2012, Badania marketingowe w podejmowaniu decyzji menedżerskich, Politechnika Lubelska, Lublin.

Smith P.R., 1993, Marketing Communications. An Integrated Approach, Kogan Page, London.

Solberg Søilen K., 2013, Exhibit Marketing and Trade Show Intelligence: Successful Boothmanship and Booth Design, Springer-Verlag, Berlin - Heidelberg.

Stolecka-Makowska A., Wolny R., 2014, Możliwości zastosowania techniki okulograficznej w ilościowych badaniach marketingowych, Studia Ekonomiczne, nr 195, s. 197-205.

Traczyk J., Kus J., Sobkow A, 2016, Affective response to a lottery prize moderates processing of payoffs and probabilities: An eye-tracking study, Polish Journal of Applied Psychology, vol. 14, iss. 4 , s. 35-46.

Turner M.M., Skubisz Ch., Pandya S.P., Silverman M., Austin L.L., 2014, Predicting visual attention to nutrition information on food products: The influence of motivation and ability, Journal of Health Communication, vol. 19, iss. 9, s. 1017-1029.

Was Ch., Sansosti F.,'Morris B., 2017, Eye-Tracking Technology Applications in Educational Research, IGI Global, Hershey.

Wästlund E., Shams P., Otterbring T., 2018, Unsold is unseen ... or is it? Examining the role of peripheral vision in the consumer choice process using eye-tracking methodology, Appetite, vol. 120, s. 49-56.

Wawer R., Pakuła M., 2012, Zastosowanie techniki eyetrackingowej do analizy postrzegania historycznej przestrzeni wystawienniczej przez osoby starsze i młodziez - teoretyczne i metodologiczne podstawy badań, Zeszyty Naukowe Uniwersytetu Szczecińskiego, nr 703. Ekonomiczne Problemy Usług, nr 88, Gospodarka elektroniczna: wyzwania rozwojowe, t. II, s. 698-707.

Wąsikowska B., 2015, Zastosowanie technik neuronauki poznawczej w zarządzaniu marketingowym, Zeszyty Naukowe SGGW w Warszawie. Polityki Europejskie, Finanse i Marketing, nr 13(62), s. $145-156$.

Zambarbieri D., Carniglia E., Robino C., 2008, Eye tracking analysis in reading online newspapers, Journal of Eye Movement Research, vol. 2, no. 4, s. 1-8. 